general application, and a large number of men trained in specific applications.

Pointing out that the new and wider understanding of science and technology on the part of the population in general is likely to lead to government playing a bigger part in the development of science and technology than in the past, Dr. Jewett insists that the functions of a director of research are essentially to provide a proper atmosphere in which men with creative ideas can work freely; to map out the general fields in which progress appears to lie; and finally to weigh the results of research work with many other factors in deciding how to proceed.

A number of Dr. Jewett's points have already been made in the report of the Parliamentary and Scientific Committee on "Scientific Research and the Universities" ; the picture in Britain is not likely to be very dissimilar from that in the United States. In spite of reference to the question of freedom of intercourse and discussion and publication of results in the House of Lords debate on scientific research and elsewhere, this aspect has as yet attracted little attention, although there are signs of a more generous attitude towards publication on the part of industrialists. In that respect, however, apart altogether from the inevitable restrictions imposed by the War, British industry has lagged far behind industry in the United States. Dr. Jewett's address is to be welcomed on that ground alone- that it emphasizes once more the vital importance of freedom of communication to all creative and fundamental scientific investigation. No post-war plans for stimulating research in industry or elsewhere will have their full effect unless they establish the conditions in which such intercourse has the maximum encouragement.

\section{GEOPHYSICAL EXPLORATION IN CANADA AND THE UNITED STATES}

$\mathrm{E}$ VIDENCE concerning geological formations near the surface of the earth, and down to depths of, say, less than one mile, can be obtained by geologists by examining the strata immediately accessible at the surface, and by inference from known similar formations, by skilfully extrapolating down to the required depth. When this process becomes somewhat risky and the formations are economically important, the sinking of boreholes at carefully selected critical places is then undertaken. These, however, are normally costly, and in their place, many companies have undertaken in recent years the geophysical surveys which, though less costly than the sinking of boreholes, have provided just that extra information which the geologist required, and that in reasonable time.

The geophysical methods of surveying may roughly be divided into four types, namely, the electrical, gravitational, magnetic and seismic, and in each of these, due to the large amount of experimental work done, great improvement in technique and in the consequent accuracy of the results has been achieved. The Rev. James B. Macelwane, S.J., of St. Louis, has recently reviewed the work done in the United States and Canada during the years 1924-39 ("Fifteen Years of Geophysics: a Chapter in the Exploration of the United States and Canada, 1924-1939." By James B. Macelwane. Geophysics, 5, No. 3; July 1940).
Before 1924, according to the author, knowledge of geophysical methods of prospecting was not widely spread in America. In March of that year the Nash salt-dome was discovered by the torsion-balance method; in October the Orchard dome was discovered by the seismic method, and the Long Point dome by the torsion-balance and seismic methods. The current value of a new dome was between 500,000 and $1,000,000$ dollars; so with the beginning of 1925, the use of the torsion-balance and seismic methods began to expand rapidly in America.

Seismic Methods. The years $1925-29$ constitute the era of whirlwind seismic refraction reconnaissance. The mechanical seismographs gave place to electromagnetic seismographs, and the sound wave to precise surveying and radio signals. Up to 1929 , according to Heiland, considerable areas had been explored in Alabama, California, Kansas, Lcuisiana, Mississippi, Now Mexico, Oklahoma and Texas. Karcher, Eckhardt and McCollom had been experimenting with a reflexion seismograph, and it was at this stage that the Geophysical Research Corporation took the matter up and developed the modern multitrace reflexion seismograph which has played so large a part in subsequent work. The seismic reflexion method has played an important part in this work of determining underground structure by means of artificial earthquakes since the year 1929 .

In the United States of America the mid-continental area was the first to be surveyed in this way, and it was not until 1932 that this method was extensively used in the Texas-Iouisiana Gulf Coast area. Now the seismic reflexion method is second only to the drill in the precision with which it is able to determine depths and outline structures. Secrecy is still maintained by some companies concerning the extent of this type of work undertaken by them.

Magnetic Methods. The magnetic method was in extensive use in North America from 1927 onwards. It is relatively inexpensive and the use of magnetometers simple, but so far as petroleum is concerned the magnetometer results are difficult to interpret with precision. Consequently, for petroleum surveys, the use of the magnetic method had largely ceased by 1931 for anything except preliminary surveys. In the mining field, however, its use has been practically continuous. Most of the central plains and coastal areas of the United. States had been surveyed by this method up to 1939, and in Canada it had been used in the Provinces of Quebec, Ontario, New Brunswick, Nova Scotia and British Columbia.

Gravitational Methods. The two types of instruments used for these surveys are the torsion balance and the gravity meter. The torsion balance had excellent success in the Gulf Coast from the start in 1924; but it had reached its peak in 1931 and by 1937 was very little used in North America. Fieldworthy and sufficiently sensitive gravimeters were developed during 1937-38, and in the period immediately prior to the present War, field work with these was being conducted over extensive areas in the United States of America. According to Macelwane, so rapidly may these surveys be conducted, and so difficult and slow is the process of adequate interpretation of the data thus obtained, that there has accumulated in the files of most companies an undigested mass of differential or relative gravity values the meaning of which is not altogether clear.

Electrical Methods. These have proved most useful in the mining field. They were found to be inferior to the seismic and gravity methods in prospecting 
for petroleum. Some of the electrical methods are used with geochemical prospecting because there would seem to be a connexion between certain electrical anomalies and geochemical prospects. By 1929, electrical surveys had been conducted in Alaska and sixteen States in America besides the Canadian Provinces of British Columbia, Manitoba, Nova Scotia, Ontario and Quebec, and in New. foundland.

\section{FORTHCOMING EVENTS}

(Meeting marked with an asterisk * is open to the public)

\section{Saturday, April 22}

British Institute of RADIOLOGY (in the Reid-Knox Hall, 32 Welbeck Street, London, W.1), at 2.30 p.m.-Dr. J. Blair Hartley "The Future of Radiology in Obstetrics".

Instirute of Physics (Industrial Rapiology Group) (at the Roval Institution, 21 Albemarle Street, Piccadilly, London, W.1) at 2.30 p.m.-Mr. W. H. Glaisher, Dr. W. Betteridge and Mr. R. Eborall: "The Mottling of Aluminium Alloy Radiographs".

Institute of Physics (Scotrish BRANCH) (in the Chemistry Buildings, The University, Glasgow), at 2.30 p.m.-Inaugural Meeting. in S. E. R. Davies: "High.Speed Photography, and its Applications

\section{Monday, April 24}

RoYal Society of ARTs (at John Adam Street, Adelphi, London, W.(.2), at 1.45 p.m.-Sir A. H. Roy Fedden: "The Future of Commercial Aviation" (Cantor Lecture).

INSTITUTion of Electrical ENGINEeRs (at Savoy Place, Victoria Embankment, London, W.C.2), at 5.30 p.m.-Discussion on "Fuel and Mechanical Power' (to be opened by Mr. J. F. Field).

\section{Tuesday, April 25}

ROYAL SOCIETY OF ARTS (DOMINIONS AND Colonies SECTION) (at John Adam Street, Adelphi, London, W.C.2), at 1.45 p.m.-Mr. A. P. van der Post: "Secondary Industries in South Africa". ROYaL ANThroporogrcat INSTITUTe (at, 21 Bedford Square, London, W.C.1), at 1.30 p.m.-Mr. David M. Fulcomer: "Bereavement as a Field for Research; an Introduction with Special Reference to Recent Research on Bereaved Spouses".

\section{Wednesday, April 26}

RoYal SocIETy of ARTs (at John Adam Street, Adelphi, London, W.C.2), at 1.45 p.m.-Mr. G. Samuel: "Some General Aspects of Potato Production in Great Britain".

PhYSICAL Society (at the Royal Institution, 21 Albemarle Street London, W.1), at 5 p.m.--Prof. Joel H. Hildebrand: "The Liquid State" (Twenty-eighth Guthrie Lecture).

\section{Thursday, April 27}

INSTITUTION OF ElectRICAL ENGINEERS (at Savoy Place, Victoria Embankment, London, W.C.2), at 5.30 p.m.-Prof. E. C. Stoner, F.R.S.: "Magnetism in Theory and Practice" (Thirty-fifth Kelvin

BRITISH INSTITUTION OF RADIO ENGINEERS (LONDON SECTION) (at the Institution of Structural Engineers, 11 Upper Belgrave Street, London, S.W.1), at 6 .
Wired Broadcasting".

\section{Saturday, April 29}

BRITrsh Rheologrsts' CuOB (at the Shirley Institute, Didsbury, Manchester), at 10 a.m.-Discussion on "Elastic Behaviour of Textile Materials"'.

Association for ScIENTIFTC Photography (at the Caxton Hall, Westminster, London, S.W.1), at 2.30 p.m.- "Photography as a Too in Agriculture"' (Papers will be read by Dr. E. N. Crook and Mr. V. Stansfleld, and by a Representative of the National Institute of Agricultural Engineering)

Physical Society (at the new Clarendon Laboratory, Oxford), at 2.30 p.m.-Prof, Joel H. Hildebrand : "The Liquid State" (Twentyeighth Guthrie Lecture).

\section{APPOINTMENTS VACANT}

APPLICA!rons are invited for the following appointments on or before the dates mentioned

ASSISTANT MASTER to teach ELECTRICAL ENGINEERTNG to Ordinary National Certificate standard in the Openshaw Technical SchoolThe Director of Education, Education Offee, Deansgate, Mancheste (April 28).

Heriot-Watt College, Edinburgh (April 28)

LECTURER (full-time) IN Chemistry-The Principal, Acton Technical College, High Street, London, W.3 (April 29)

Psychiatric Soclas Worken to work with the Psychiatrist and Educational Psychologist in the Child Guidance Clinic-The Director of Education, Education Office, Town Hall, Barnsley (April 29).
RESEARCH METALLURGIST, preferably with knowledge of ENGINEER ING, by well-known North Country firm specializing in the Use and Heat Treatment of High-Carbon and Alloy Steels- The Ministry of Register, Room 432, Alexandra House, Kingsway, London, W.C.2 (quoting Reference No. F.2019XA) (April 29).

ProfESSORSHIP OF ENGINEERING SCIENCE-The Registrar, University Registry, Oxford (April 30).

GDUcational PSYChologist, and a Psychiatrist SOCIAL WORKer -The Secretary for Education, County Education Offices, North ampton (May 1).

LECTORER (fuli-time) IN CHEMISTRY at the Cardiff Technical College The Director of Education, Education Offices, Cardiff (May 1).

CHAIR OF PHILOSOPHY at the University of the Witwaterstand, Johannesburg-Dr. William Cullen, 4 Broad Street Place, London,
E.C.2 (May 1).

ENGINEERINA WORKSHOP INSTRDCTOR in the Mechanical Engineering Department, a Tracher of Sctence AND MATHEMATICS, and a TEACHER OF WOODWORK, BUILDING CONSTRUCTION AND GEOMETRY, in the Junior Technical School of the Barnsley Mining and Technical College-The Principal, Technical College, Church Street, Barnsley (May 1).

LeCTURer IN ORganio Chemistry in the Brighton Technical College-The Education Officer, 54 Old Steine, Brighton (May 4)

VICE-PRINCrPAI of the Brighton Technical College (the post will be embodied with that of Head of the Civil Engineering and Building Department)-The Edncation Offcer, 54 Old Steine, Brighton (May 4) DIS'ment FNGINEER by the Ceylon Government Railway- The Ministry of Labour and National Service, Room 432, Alexandra House, Kingsway, London, W.C.2 (quoting Reference No. E.926A) (May 10). SENIOR POST under the AFRONAUTICAT INSPECTION DIRECTORATE applicants should possess a flrst-class Honours Degree in Physics or a recognized equivalent, have had industrial radiological experience, be conversant with the various modiflcations of the technique of X-ray crystal analysis, and be capable of carrying out independent ad hoc scientific investigations in electro-physics- The Ministry of Labour and National Service, Room 432, Alexandra House, K

don, W.C.2 (quoting Reference No. A.499A) (May 10).
DIRECTOR OF THE INSTITUTE OF MEDIOAL AND VETERINARY ScIENCE, Adelaide-The Agent-General and Trade Commissioner for South Adelaide-The Agent-General and Trade Commissioner for South
Australia, South Australia House, Marble Arch, London, W.1 (Mav 31).

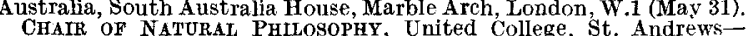
CHAIR OF NATURAL PHLlosopHy, United College,
The Secretary, The University, St. Andrews (June 15).

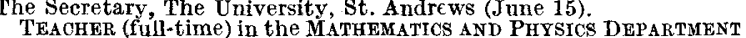
-The Principal, Municipal Technical College, Hopwood Lane, Halifax, MEN qualified to teach MATHEMATros, SOIENCE and MaOHINE DRAwING, at the Wakefield Technical College-The Director of DRAWING, at the Wakefield Technical

Grucation, 27 King Street, Wakefleld. MRADUATE ASSISTANT (temporary) with special qualifications in MECHANICAL ENGINEERING, a GRADUATE ASSISTANT (temporary) with First- or Second-Class Honours or Higher Degree (temporary) with MATics or PHYSICS, and a well-qualified ASSISTANT (temporary) with pal, Mining and Technical Institute, Neath, Glam.

PRINCIPAI OF The ROYal HollowaY CoLlege-The Secretary to the Governors, Royal Holloway College, Englefield Green, Surrey.

\section{REPORTS and other PUBLICATIONS (not included in the monthly Books Supplement)}

\section{Great Britain and Ireland}

Medical Research Council. War Memorandum No. 11 : The Con. trol of Cross Infection in Hospitals. Pp. 34. (ILondon: H.M. Stationery Office.) 6d.net. Report Session 1942-43. Pp. $32+2$ plates. (London: South-West Essex Technical College and School of Art, Walthamstow.) [223 Geological Survey of Great, Britain: Scotland. War-time Pamphlet No. 13: Limestones of Scotland, Area 1: Southern Scotland. By Dr. J. B. Simpson; with Analyses by Dr. A. Muir and H. G. M. Hardie. Pp. 24. (London: Geological Survey and Museum.)
$[223$ 18. Medical Research Council. War Memorandum No, 12: The Use of Penicillin in treating War Wounds. (Instructions prepared by the Penicillin Clinical Trials Committee.) Pp. 16. (London: H.M. Stationery Office.) $3 d$.net.

\section{Other Countries}

Ieague of Nations: Economic, Financial and Transit Department. Agricultural Production in Continental Europe during the 1914-18 War and the Reconstruction Period. (Publication 1943 II.A.7.) Pp. 122. (Geneva : League of Nations; London: George Allen and Unwin, Ltd.) $7 s .6 d$. League of Nations. Report ontary-General. (Publication, Gencral, 1943,1.) Pp. 117. (Geneva : League of Nations; London: George Allen and Unwin, Ltd.) $2 s$.

Report on the Operations of the Department of Agriculture, Burma for the Years 1941-42 and 1942-43. Pp. 26. (Simla: Dopartment of Agriculture, Burma.)
Eommonwealth of Australia : Council for Scientifle and Industria] Research. Bulletin No. 169: The Entomological Control of St. John' Wort (Hypericum perforatum L.), with particular reference to th Insect Enemies of the Weed in Southern France. By Frank Wilson. Pp. 87. Bulletin No. 171: Experiments with Insecticides against th Red-legged Earth Mite (Halotydeus destructor (Tucker).). By K. R. Norris. Pp. 28. (Melhourne : Government Printer.) Association of Scientific Workers of Southern Africa. Research Memorandum 2: Considerations for Planning Farming in South Africa. Pp. 22. 18. 6d. Research Memorandum 3: The Native Reserves and Post-War Reconstruction. By Edward R. Roux. Pp. 12 . Africa.) 